\title{
Flower size dimorphism, perianth shape and sex ratio in a gynodioecious Prunella vulgaris (Lamiaceae)
}

\author{
Vladimir Godin ${ }^{1, *}$, and Tatyana Arkhipova ${ }^{1}$, and Natalia Meier ${ }^{2}$ \\ ${ }^{1}$ Moscow Pedagogical State University, 129164, Moscow, Kibalchicha str., 6, bldg. 3, Russia \\ ${ }^{2}$ Ludwig-Maximilians-University Munchen, D-80539, Geschwister-Scholl-Platz, 1, Germany
}

\begin{abstract}
Prunella vulgaris is a gynodioecious species that forms two types of flowers, perfect and female, on different plants. These two sexual types of flowers have significant differences in some characters of calyx, corolla, androecium, and gynoecium. The distinctiveness of gynodioecy in $P$. vulgaris consists in insignificant size differences in anthers, the formation of sterile pollen in female flowers, and the shape of a corolla in two sexual types of flowers. Hermaphrodite plants are dominated in $P$. vulgaris (59.8 to 87 percent). In flood plain meadows, the proportion of females is significantly higher (from 25.9 to 40.2 percent) than in dry and forest meadows (from 13 to 19.1 percent).
\end{abstract}

\section{Introduction}

A gynodioecy is a sexual dimorphism when there are two types of plants: hermaphrodite (with perfect flowers) and female (with pistillate flowers). Gynodioecy is quite common in temperate flowering plants and is often found in the Lamiaceae. Currently, the family contains 252 gynodioecious species (3.2 percent) and 46 genera (18.8 percent) $[1,2]$. The gynodioecy in flowering plants, and in the Lamiaceae, in particular, consists in larger perfect and smaller female flowers [3].

Common Selfheal (Prunella vulgaris L., Lamiaceae) is a perennial herbaceous longrhizome or racemose polycarpic plants [4]. Common Selfheal has a circumboreal area. $P$. vulgaris is an assectator, found in pine, spruce-pine, birch forests, dry and forest meadows, and mesophytes. P. vulgaris grows in forests, wood margins and glades, coppices, dry meadows, sides of irrigation ditches, and shores of lakes [4].

Initially, gynodioecy in P. vulgaris was described by H. Muller [5], who noted two types of flowers: large-flowered hermaphrodite and small-flowered female. Later P. Knuth [6] reported that $P$. vulgaris has three types of flowers: large hermaphrodite flowers; medium-sized flowers, hermaphroditic or with partially or completely aborted androecium (female), and small flowers, hermaphroditic or female with androecium reduction. However, later researchers did not note the existence of two sexual types of flowers [7, 8]. Data on the sex ratio in P. vulgaris are scarce. According to P. Knuth [6], in populations of $P$. vulgaris from Western Europe (Germany), there are up to 50 percent of females, the

*Corresponding author: vn.godin@mpgu.su 
average frequency of which is 10 to 20 percent. According to E.I. Demyanova [9], in the Perm region, the frequency of hermaphrodite plants varies from 58.9 to 88.9 percent. This work aims to show the size differences in perfect and female flowers and the sex ratio in $P$. vulgaris in the Moscow region.

\section{Materials and methods}

Our studies were carried out in natural conditions of the Moscow region from 2016 to 2020. The sex ratio of populations was analyzed using the method of running lines. We analyzed 10 populations of $P$. vulgaris in different types of meadows (dry, forest, and flood plain). The first five populations were included in different types of flood plain meadows, while the others were described in dry and forest meadows. In each population, we counted at least 100 flowering plants of different sexes. The morphology of 100 female and 100 perfect flowers was studied. The sizes of flower parts were measured using a Biomed MS-1 stereoscopic microscope. We measured the other parts of the flower: calyx (length of upper lip, length of lower lip, width of lobes of lower lip, length of tube, height of fauces), corolla (length of lower lip, length and width of middle lobe of lower lip, length and width of lateral lobes of lower lips, length of upper lip, length of tube, height of fauces), androecium (length of lower stamens, length of free parts of lower stamens, length of upper stamens, length of free parts of upper stamens, length and width of anther, length of subulate outgrowth of lower stamens), gynoecium (length of style, length and width of stigma lobes, length and width of ovary lobes, length of anterior lobe of nectar disc). We studied the pollen of 50 perfect and 50 female flowers in three characters: equatorial diameter and polar axis of pollen grains, $\mu \mathrm{m}$; pollen fertility, percentage. For measurements, 10 fertile and 10 sterile pollen grains were taken from each flower. The measurements were carried out using a Biomed-5 microscope with an eyepiece micrometer at a magnification of $7 \mathrm{x}$ 40. All data were processed by the methods of variation statistics [10].

\section{Results}

In the Moscow region, $P$. vulgaris has two types of flowers, perfect and female, produced on different plants (gynodioecy). However, P. vulgaris has some distinctiveness that is somewhat different from other gynodioecious species of the Lamiaceae (Table 1).

\subsection{Flower size dimorphism and perianth shape}

Perfect and female flowers do not differ in the perianth. As in other gynodioecious species, significant differences in the sizes of all parts of the calyx and corolla were revealed between these types of flowers. Perianth parts of perfect flowers are always larger than female ones (Table 1). Thus, there are significant size differences between perfect and female flowers of $P$. vulgaris in the perianth parts, as in other gynodioecious species of the Lamiaceae [1, 3]. However, the degree of dimension differences in the perianth of $P$. vulgaris has its own characteristics. Therefore, we compared the size of perfect and female flowers in P. vulgaris and in another species of the same family, Schizonepeta multifida [11]. The corolla parts of perfect flowers in Schizonepeta multifida are 65 to 80 percent larger than female flowers, while in $P$. vulgaris they are only 35 to 55 percent larger. Thus, between perfect and female flowers in Schizonepeta multifida, greater size differences in the corolla are observed. Therefore, the sexual type of flowers in Schizonepeta multifida is easier to distinguish in the corolla than in $P$. vulgaris. 
Furthermore, the perfect and female flowers of $P$. vulgaris differ in the corolla shape. In perfect flowers, the angle between the lower lip of the corolla and the middle lobe of the upper lip is about 90 degrees. As such, perfect flowers look wide open and their stamens and stigma are clearly visible. In contrast, in female flowers, the lower lip of the corolla and the middle lobe of the upper lip are almost parallel. As a result, female flowers appear to be half-open with their stamens and stigmas invisible.

Table 1. Some signs of perfect and female flowers in Prunella vulgaris

\begin{tabular}{|c|c|c|c|c|}
\hline Signs & Flower & Min-Max & $\mathrm{M} \pm \mathrm{m}$ & $\mathrm{P}$ \\
\hline Length of the upper lip of the calyx, mm & $\begin{array}{l}\mathrm{p} \\
\mathrm{f}\end{array}$ & $\begin{array}{c}8.3-10.3 \\
7.0-9.0\end{array}$ & $\begin{array}{l}9.4 \pm 0.32 \\
8.2 \pm 0.22\end{array}$ & 0.002 \\
\hline Length of the lower lip of the corolla, $\mathrm{mm}$ & $\begin{array}{l}\mathrm{p} \\
\mathrm{f}\end{array}$ & $\begin{array}{c}13.8-16.2 \\
9.0-11.0\end{array}$ & $\begin{array}{c}15.0 \pm 0.38 \\
9.8 \pm 0.40\end{array}$ & $1.7 * 10^{-15}$ \\
\hline Length of the corolla tube, $\mathrm{mm}$ & $\begin{array}{l}\mathrm{p} \\
\mathrm{f}\end{array}$ & $\begin{array}{c}9.8-11.7 \\
5.8-8.1\end{array}$ & $\begin{array}{c}10.6 \pm 0.32 \\
6.8 \pm 0.40\end{array}$ & $3.7 * 10^{-11}$ \\
\hline Length of lower stamens, $\mathrm{mm}$ & $\begin{array}{l}\mathrm{p} \\
\mathrm{f}\end{array}$ & $\begin{array}{c}12.3-15.0 \\
8.5-10.5\end{array}$ & $\begin{array}{c}13.9 \pm 0.44 \\
9.3 \pm 0.34\end{array}$ & $6.1 * 10^{-13}$ \\
\hline Length of anthers, $\mathrm{mm}$ & $\begin{array}{l}\mathrm{p} \\
\mathrm{f}\end{array}$ & $\begin{array}{l}0.70-0.85 \\
0.65-0.75\end{array}$ & $\begin{array}{l}0.77 \pm 0.02 \\
0.70 \pm 0.02\end{array}$ & $\mathbf{0 . 0 2 3}$ \\
\hline Polar axis of pollen, $\mathrm{mm}$ & $\begin{array}{l}\mathrm{p} \\
\mathrm{f}\end{array}$ & $\begin{array}{l}40.0-43.8 \\
31.3-35.0\end{array}$ & $\begin{array}{l}42.0 \pm 0.32 \\
33.1 \pm 0.49\end{array}$ & $1.3 * 10^{-27}$ \\
\hline Length of style, mm & $\begin{array}{l}\mathrm{p} \\
\mathrm{f}\end{array}$ & $\begin{array}{l}13.8-16.2 \\
10.0-12.0\end{array}$ & $\begin{array}{l}15.0 \pm 0.38 \\
10.9 \pm 0.34\end{array}$ & $1.6 * 10^{-12}$ \\
\hline Length of ovary lobes, $\mathrm{mm}$ & $\begin{array}{l}\mathrm{p} \\
\mathrm{f}\end{array}$ & $\begin{array}{l}0.55-0.65 \\
0.55-0.70\end{array}$ & $\begin{array}{l}0.60 \pm 0.02 \\
0.63 \pm 0.03\end{array}$ & 0.325 \\
\hline
\end{tabular}

Note. $\mathrm{p}$ - perfect flowers, $\mathrm{f}$ - pistillate flowers. Significant differences are shown in bold.

In female flowers of $P$. vulgaris, stamens are represented by staminodes. The female flowers of $P$. vulgaris form pollen grains like perfect flowers, but their pollen is completely sterile. For instance, the anthers of female flowers in Schizonepeta multifida is almost 450 percent shorter than the anthers of perfect flowers, while in $P$. vulgaris this difference is only 10 percent. A similar situation was described in Ajuga reptans L. [12]. In Schizonepeta multifida, the stamen abortion occurs in the early stages of flower development while in Prunella vulgaris and Ajuga reptans it happens in the latest stages. We proposed that these insignificant size differences in perfect and female stamens are the main reason for not identifying two types in P. vulgaris $[7,8]$. We learned the dimension differences in pollen grains of perfect and female flowers. In female flowers, pollen grains are almost spherical and their equatorial diameter and polar axis are significantly smaller than in pollen grains of perfect flowers (Table 1). The gynoecium of perfect and female flowers of $P$. vulgaris does not differ. Nevertheless, the style and stigma lobes are longer in perfect flowers (Table 1). Female flowers have wider stigma lobes. The two sexual types of flowers do not significantly differ in the size of the ovary blades and nectar disc.

There are three hypotheses to explain the size differences in the perianth: "malecompetition", "developmental-correlation", and "enclosing-function" [3]. The "developmental-correlation" hypothesis suggests that there is consistent growth and/or genetic correlation between petals and stamens. Several researchers have shown that the growth of the corolla is influenced by hormones secreted by the stamens. Numerous studies $[13,14]$ have established that the corolla size of female flowers in gynodioecious species is affected by the time of anther and pollen reduction. If such reduction of the androecium occurs at the later stages of development, this has little effect on the perianth size of female flowers. The mutual influence of developing petals and stamens in a flower was convincingly demonstrated by $\mathrm{ABC}$ and later $\mathrm{ABCDE}$ by a molecular biological model of flower development $[15,16]$. According to the ABCDE model, the development of calyx, 
corolla, androecium, and gynoecium in flowers is determined by genes belonging to five classes (A, B, C, D and E). The products of genes A $+B+E$ are necessary for the formation of petals and $\mathrm{B}+\mathrm{C}+\mathrm{E}$ are for stamens [17]. There are at least two groups of genes (B and $\mathrm{E}$ ) that determine the development of petals and stamens. Perfect flowers of gynodioecious species have fertile pollen, while females are completely devoid of it. The perianth of perfect flowers protects the androecium and gynoecium, while in female flowers it only protects the gynoecium. The success of polleniferous plants (hermaphrodite plants in gynodioecious species) is directly related to their ability to form and receive pollen, while the success of females only depends on their ability to perceive pollen. Therefore, the petals of perfect flowers must be larger than those of female flowers due to the hormones that form the stamens. This is necessary to protect greater generative organs (androecium and gynoecium) or to be attractive to pollinators compared to female flowers. Although a hormonal signal produced by stamens and pollen may be the cause of the size dimorphism of flowers, the ultimate cause may be natural selection, which makes perfect plants more attractive. Many surveys show pollinators visit large perfect flowers more often than small females $[3,13,14]$. However, the formation of large flowers is limited by the available resources. Consequently, there is a potential conflict in gynodioecious plants: to form larger flowers, but in a smaller number, or smaller flowers, but in a larger number. It has been experimentally shown [3] that the formation of a smaller number of larger flowers is the most optimal strategy for hermaphrodite plants of gynodioecious species since the process of forming additional flowers requires the expenditure of numerous energy resources. Plants with smaller flowers can produce more seeds than plants with larger flowers. Therefore, as most researchers propose, the relative sizes of flowers are adaptive traits. The size of the flowers is often used by pollinators to indicate how useful a flower can be. This signal is likely to be reliable in gynodioecious plants since hermaphrodite flowers usually contain more nectar than pistillate flowers of the same species [3].

\subsection{Sex ratio}

According to our studies, hermaphrodite plants predominate in the populations of $P$. vulgaris, the frequency of which varied from 59.8 to 87 percent. However, in flood plain meadows, the portion of females is significantly higher than in dry and forest meadows. Thus, in flood plain meadows, the frequency of females varied from 25.9 to 40.2 percent, and 13 to 19.1 percent in dry and forest meadows. Our data is consistent with the information available in the literature on the sex ratio in populations in Western Europe. Alternatively, the closeness of the obtained data is due to rather similar ecological conditions of the Moscow region and Germany. According to E.I. Demyanova [9], females in $P$. vulgaris populations are quite rare, which is most likely because the study area belongs to the zone of meadow steppes and steppe meadows. P. vulgaris is a boreal species, most often found in wet meadows. More arid conditions (meadow steppes and steppe meadows) are likely to negatively affect females. Numerous studies have shown that the female plants of gynodioecious species greatly suffer from the lack of atmospheric and soil moisture, which leads to a significant decrease of their frequency in population $[1,9]$.

In marked hermaphrodite and female $P$. vulgaris plants, any change in the sex of plants was not revealed over five years of our observation. Thus, $P$. vulgaris does not show a change in the sexual status of flowers and, accordingly, plants in general. For five years of observation, the ratio of hermaphrodite and female plants within each population did not undergo noticeable changes over time $(\mathrm{G}=0.178-0.291, \mathrm{P}=0.999)$. Consequently, the sex ratio in $P$. vulgaris is fairly stable. 
It is possible to assume the reasons for the frequencies of hermaphrodite and female plants in populations. According to the literature, the most studied gynodioecious species have the nuclear-cytoplasmic inheritance of gynodioecy [18]. A way for the sex determination presupposes the presence in populations of hermaphrodite plants with different genotypes. An indirect confirmation of this assumption is in different parts of the $P$. vulgaris area as there is inconsistent data about the system of self-incompatibility and the ability to autogamy. According to one group of authors [19], P. vulgaris is a selfincompatible species in which seeds are set as a result of cross-pollination by insects. Alternatively, according to other group of authors [7-9], P. vulgaris is a self-compatible species in which most of the seeds are set as a result of contact autogamy. It is possible that both groups of researchers are correct. As is known from the example of the inheritance of gynodioecy in Origanum vulgare [20], hermaphrodite plants of various genotypes are found in its populations, some of which are self-compatible and some are selfincompatible. We suppose that $P$. vulgaris has a similar pattern of inheritance of gynodioecy, like in Origanum vulgare, since the frequencies of females in the populations of both species are quite similar. The nuclear-cytoplasmic sex inheritance in $P$. vulgaris explains the disagreements in the literature regarding the crossing system of this species.

\section{References}

1. V. N. Godin, Botanical J. 104 (2019)

2. V. N. Godin, Botanical J. 105 (2020)

3. L. F. Delph, L. F. Galloway, M. L. Stanton, American Naturalist 148 (1996)

4. R. M. Harley, S. Atkins, A. L. Budantsev, P. D. Cantino, B. J. Conn, R. Grayer, M. M. Harley, R. de Kok, T. Krestovskaja, R. Morales, A. J. Paton, O. Ryding, T. Upson, Labiateae, in Flowering Plants. Dicotyledons: Lamiales (except Acanthaceae including Avicenniaceae), Springer Science \& Business Media 7 (2004)

5. H. Muller, The fertilization of flowers, London (London, Macmillan, 1883)

6. P. Knuth, Handbuch der Blütenbiologie (Leipzig, 1898)

7. J. A. Solomon Raju, J. of Nature Conservation 7 (1995)

8. T. C. Ling, L. L. Wang, Z. Q. Zhang, A. Dafni, Y. W. Duan, Y. P. Yang, Plant Ecology and Evolution 150 (2017)

9. E. I. Demyanova, Primorsky University Bulletin. Biology 2 (2020)

10. R. R. Sokal, F. J. Rohlf, Biometry: the principles and practice of statistics in biological research (New-York, 2012)

11. V. N. Godin, Botanical J. 94 (2009)

12. V. N. Godin, L. R. Akhmetgarieva, Botanical J. 104 (2019)

13. M. L. Van Etten, S. M. Chang, Ann. Bot. 114 (2014)

14. M. K. Oak, J. H. Song, S. P. Hong, Plant Syst. Evol. 304 (2018)

15. G. W. Haughn, C. R. Somerville, Developmental Genetics 9 (1988)

16. G. Theißen, Current Opinion in Plant Biology 4 (2001)

17. J. Liu, C.-Q. Li, Y. Dong, X. Yang, Y.-Z. Wang, BMC Plant Biology 18 (2018)

18. M. F. Bailey, L. F. Delph, Oikos 116 (2007)

19. S. I. Warwick, D. Briggs, New Phytologist 83 (1979)

20. D. Lewis, L. K. Crowe, Evolution 10 (1956) 